\title{
Model Pembelajaran Berbasis Aktivitas pada Siswa Kelas VII di MTs Al-Hidayah Sungai Tabukan
}

\author{
Ramdhani \\ Guru MTs Al-Hidayah Sungai Tabukan, Kabupaten Hulu Sungai Utara, Kalimantan Selatan, Indonesia \\ email: ramdanialabio@gmail.com (Corresponding Author)
}

\begin{tabular}{|c|c|}
\hline (A) Check for updates open access @) (1) & DOI: https://doi.org/10.53621/jider.v1i3.59 \\
\hline Informasi Artikel & ABSTRAK \\
\hline $\begin{array}{l}\text { Riwayat Artikel: } \\
\text { Diterima: } 06 \text { Oktober } 2021 \\
\text { Revisi Akhir: } 23 \text { November } 2021 \\
\text { Disetujui: } 15 \text { Desember } 2021 \\
\text { Terbit: } 31 \text { Desember } 2021 \\
\end{array}$ & $\begin{array}{l}\text { Tujuan penelitian ini untuk mengetahui dan mendeskripsikan tingkat } \\
\text { pendekatan berbasis aktivitas dalam menumbuhkan motivasi belajar } \\
\text { aqidah akhlak pokok bahasan Taubat MTs Al-Hidayah Sungai Tabukan } \\
\text { pada siswi kelas VII B pada semester I tahun pelajaran 2020/2021. } \\
\text { Penelitian ini merupakan penelitian tindakan kelas yang ingin }\end{array}$ \\
\hline $\begin{array}{l}\text { Kata Kunci: } \\
\text { Model aktivitas belajar, } \\
\text { Pelajaran Aqidah akhlak, } \\
\text { Hasil belajar kelas VII, } \\
\text { MTs. Al-Hidayah Sungai } \\
\text { Tabukan. }\end{array}$ & $\begin{array}{l}\text { mengungkap seberapa tinggi tingkat efektifitas pendekatan berbasis } \\
\text { aktivitas dalam menumbuhkan motivasi belajar aqidah akhlak pokak } \\
\text { bahasan Taubat pada siswi kelas VII. Lokasi penelitian tindakan ini adalah } \\
\text { Madrasah Tsanawiyah Al-Hidayah Sungai Tabukan, kelas VII B semester I } \\
\text { terdiri dari } 14 \text { siswi. Hasil penelitian menemukan bahwa pembelajaran } \\
\text { materi taubat dengan menggunakan metode Saintifik/inquiry pada siswi }\end{array}$ \\
\hline 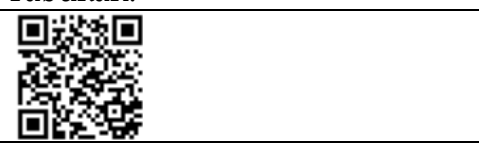 & $\begin{array}{l}\text { kelas VII B dirasa dapat meningkatkan proses pembelajaran materi taubat. } \\
\text { Dimana dapat dilihat dari peningkatan rata-rata perolehan skor dari siklus } \\
1 \text { sebesar }(85 \%) \text { dan meningkat pada siklus } 2 \text { sebesar }(95 \%) \text {. }\end{array}$ \\
\hline
\end{tabular}

\section{PENDAHULUAN}

Istilah motivasi berasal dari kata latin "movere" yang artinya bergerak (Stresser, 144t). Adapun pengertian mengenai motivasi menurut para ahli, antara lain : menurut Teaven dan Smith (146) konstruksi yang mengaktifkcan dan mengarahkan prilaku dengan memberi dorongan atau daya pada organisme untuk melakukan suatu aktivitas. Menurut Chauhan (1988) motivasi adalah suatu proses yang menimbulkan aktivitas pada organisme sehingga terjadi suatu prilaku. Wordworth (Petri, 1981; Franken, 1982) r-nengggunakan istilah Drive rtau mativasi adalah suatu kanstruksi dengan tiga karakteristik yaitu intensitas, arah dan persisten. Artinya motfvasi dengan intensitas yang cukup akan memberikan arah kepada individu untuk melakukan sesuatu secara tekun dan secara terus menerus (Djalali, 2001). Menurutnya motivasi digelongkan menjadi tiga hagian, pertama, Orgcrraik needs (kebutuhan vital, seperti: makan, minum, dan lainlain). Kedua, Emergency motives, ditirnbulkan karena suatu kebutuhan yang harus terpenuhi dan tergantung pula pada keadaan lingkungan. Ketiga, Objectives motives dan interest (L3akir, 1993).

Menurut Eysenk dan kazvankatuan motivasi dirumuskan sebagai suatu proses yang menentukan suatu tingkatan kegiatan, intensitas, konsistensi, serta arah umum dari tingkah laku manusia, merupakan konsep yang rumit dan berkaitan dengan konsep-konsep seperti minat, bakat, konsep diri, sikap dan sebagainya. Menurut Maslow $(1943,1970)$ motivasi suatu proses tingkah laku manusia yang dibangkitkan dan diarahkan oleh kebutuhan tertentu seperti harga diri diantaranya (Slameto, 2003). David McClelland, Abraham Maslow, Wan dan Brown seperti dikutip oleh Wahjosumidjo (1983), bahwa motivasi adalah suatu proses psikologis yang mencerminkan interaksi antara sikap, kebutuhan, persepsi dan kepuasan yang terjadi pada diri seseorang (Kosasih, 2004). Sedangkan menurut Mc.Donald motivasi ialah suatu perubahan energi di dalam pribadi seseorang yang ditandai dengan timbulnya afek-tif dan reaksi untuk mencapai tujuan.

Fakta dilapangan menunjukkan bahwa banyak siswi kelas VII B MTs Al-Hidayah Sungai Tabukan bersikap pasip ketika berlangsung pembelajaran di kelas. Selama pembelajaran berlangsung siswa menjadi pendengar yang baik. Ketika guru mejelaskan materi pelajaran 
kebanyakan mereka diam. Demikianpun ketika guru memberikan pertanyaan, sebagian besar siswa diam tanpa komentar. Apalagi ketika guru meminta agar siswa bertanya, merekapun diam. Fakta ini dilatar belakangi karena siswa kurang diberikan strategi pembelajaran yang memadai. Oleh sebab itu dalam proses pembelajaran di sekolah dibutuhkan kreativitas dan keaktifan seorang pengajar dalam membuat strategi belajar mengajar semenarik mungkin sehingga menimbulkan motivasi belajar siswa khususnya materi aqidah akhlak.

Sehagaimana dijelaskan diatas bahwa proses belajar yang menarik dan aktif adalah keinginan setiap praktisi pendidikan. Seorang guru dalam sebuah proses belajar mengajar dituntut untuk menggunakan berbagai metode yang menarik untuk menciptakan proses belajar yang kondusif. Salah satu metode yang menarik dalam proses belajar mengajar adalah metode pendekatan aktivitas, dimana dalam prosesnya lebih mengedepankan atau berpusat pada keaktifan siswa dalam proses belajar mengajar (Student Center). Dengan pembelajaran yang lebih menekankan pada keaktifan siswa (Student Activity) diharapkan mampu meningkatkan motivasi belajar yang pada akhirnya juga diikuti dengan hasil atau prestasi belajar sesuai dengan tujuan pendidikan.

Fenomena di atas menunjukkan bahwa proses pembelajaran dengan menekankan pada aktivitas siswa perlu dilaksanakan secara terus menerus. Hal ini dapat dilakukan apabila pola interaksi antara guru dan siswa terjalin dengan baik. Namun hal lain yang juga sangat penting dalam melaksanakan kegiatan tersebut demi meningkatkan motivasi belajar dan aktivitas siswa dalam proses belajar mengajar adalah kemampuan guru dalam merencanakan suatu proses kegitan belajar mengajar sehingga tercapai tujuan pembelajaran.

Untuk melakukan sebuah penelitian tindakan kelas dengan berfokus pada peningkatan motivasi belajar siswa dalam bidang aqidah akhlak melalui kegiatan pembelajaran berbasis aktivitas. Berdasarkan pada latar belakang tersebut diatas, maka dalam penelitian ini penetiti dapat merumuskan focus penelitian sebagai berikut bagaimana efektitifitas model pembelajaran berbasis aktivitas untuk meningkatkan motivasi belajar Aqidah Akhlak siswi kelas VII B semester 1 MTs Al-Hidayah Sungai Tabukan tahun pelajaran 2020/2021. Dengan tujuan untuk mengetahui dan mendeskripsikan tingkat pendekatan berbasis aktivitas dalam menumbuhkan motivasi belajar aqidah akhlak pokok bahasan Taubat MTs Al-Hidayah Sungai Tabukan pada siswi kelas VII B pada semester I tahun pelajaran 2020/2021.

\section{METODE PENELITIAN}

Penelitian ini termasuk jenis penelitian tindakan kelas (classroom action research) yang ingin mengungkap seberapa tinggi Tingkat efektifitas Pendekatan berbasis aktivitas dalam menumbuhkan motivasi belajar aqidah akhlak pokak bahasan Taubat pada siswi kelas VII. Lokasi penelitian tindakan ini adalah Madrasah Tsanawiyah Al-Hidayah Sungai Tabukan, kelas VII B semester I terdiri dari 14 siswi. Kondisi kelas ukuran ruangan $6 \mathrm{mX5m}$, dengan fentilasi pencahayaan ruangan cukup standard. Lama penelitian dimulai dari bulan Agustus 2020, sedangkan subjek dalam penelitian ini ditentukan berdasarkan faktor perbedaan kemampuan belajar antar siswi, dan kondisi lingkungan lokasi penelitian. Subyek penelitian ini adalah siswi kelas VII B MTs Al-Hidayah Sungai Tabukan pada tahun pelajaran 2020/2021. Penelitian ini dilakukan dua siklus

Proses Penelitian Tindakan meliputi: Refleksi awal, kelas VII B semester I materi Aqidah Akhlak sangat pasip, siswi hanya mendengar dan menyimak, bagaimana guru dapat meningkatkan motivasi belajar agar siswi aktif? Lebih lengkap dijabarkan sebagai berikut: Perencanaan Meliputi penyampaian materi Aqidah Akhlak khususnya tuabat, latihan dengan mengerjakan beberapa soal, pembahasan latihan soal, keaktifan siswa dalam menjawab pertanyaan dan motivasi siswa. Tindakan (action) kegiatan mencakup Siklus ada 2 apabila tidak terpenuhi atau tercapai hasil dimulai dari refleksi awal, kemudian dilanjutkan dengan perencanaan, tindakan, observasi dan refleksi akhir. Observasi (pengamatan) pada tahap ini peneliti akan mengadakan pengamatan hasil belajar siswi dari keaktifan siswi yaitu 1). Keaktifan siswi dalam diskusi, 2). Banyaknya siswi yang bertanya, 3). Banyaknya siswi yang menjawab 
pertanyaan guru/siswi lain, 4). Memberikan pendapat. Serta kegiatan ke empat adalah Refleksi, pada kegiatan akhir siklus perlu adanya pembahasan siklus tersebut untuk dapat menentukan kesimpulan atau hasil penelitian.

Dalam penelitian tindakan ini peneliti menggunakan beberapa prosedur pengumpulan data agar memperoleh data yang objektif. Beberapa teknik pengumpulan data yang digunakan dalam penelitian ini, antara lain: Observasi; Obsevasi diartikan sebagai pengamatan dan pencatatan secara sistematik terhadap gejala yang tampak pada objek penelitian (Zuriah, 2003). Pengamatan dan pencatatan yang dilakukan terhadap objek ditempat terjadi atau berlangsungnya peristiwa. Ada dua observasi yang dilakukan oleh peneliti dalam penelitian tindakan ini, diantaranya: (I) Obsevasi langsung, adalah pengamatan yang dilakukan dimana observer berada bersama dengan objek yang selidiki. Artinya peneliti ikut berpartisipasi secara langsung saat peristiwa terjadi. (2) Obsevasi tidak langsung, adalah observasi yang dilakukan dimana observer tidak berada bersama dengan objek yang selidiki. Tetapi, peneliti menggunakan daftar cek (Check List) dalam menggali atau mengumpulkan data ketika menggunakan terknik ini.

Wawancara merupakan salah satu prosedur terpenting untuk mengumpulkan data dalam penelitian kualitatif, sebab banyak informasi yang diperoleh peneliti melalui wawancara. Wawancara dilakukan peneliti untuk memperoleh data sesuai dengan kenyataan pada saat peneliti melakukan wawancara. Wawancara dalam penelitian ini ditujukan kepada siswi kelas VII Madrasah Tsanawiyah Al-Hidayah Sungai Tabukan.

\section{HASIL DAN PEMBAHASAN}

Deskripsi Tahap Studi Awal, data yang diperoleh dari observasi aktivitas siswa menjawab pertanyaan dengan lisan materi taubat sebagai berikut:

\begin{tabular}{|c|c|c|}
\hline No & Nama & Katagori \\
\hline 1 & Adiska & Sangat Baik \\
\hline 2 & Azizah & Sedang \\
\hline 3 & Delima & sedang \\
\hline 4 & Fitri Aziah & Baik \\
\hline 5 & Helda Wati & Sedang \\
\hline 6 & Khadijah & Sangat Baik \\
\hline 7 & Khalidah & Baik \\
\hline 8 & Mahdalina & Sangat Baik \\
\hline 9 & Mildawati & Sangat Baik \\
\hline 10 & Mutia & Sedang \\
\hline 11 & Nurul Aida & Sangat Baik \\
\hline 12 & Ratna & Sedang \\
\hline 13 & Saidatul Karimah & Sedang \\
\hline 14 & Siti Zahra & Baik \\
\hline
\end{tabular}

Tes Analisis hasil tes dilakukan untuk mengukur kemampuan berpikir kritis siswa setelah mengikuti pembelajaran dengan menggunakan metode brainstorming. Data hasil tes dianalisis berdasarkan pedoman penilaian yang telah dibuat oleh peneliti. Maka Indikator keberhasilan dalam penelitian ini adalah: Hasil siklus 2 yaitu : a. Sebanyak $\geq 95 \%$ siswi dapat memahami materi Taubat, b. Ketuntasan belajar tercapai jika 95\% siswi mendapat nilai 95, c. Untuk kriteria keaktifan siswa mendapat nilai sedang, dilihat dari hasil penilaian instrument, Menggunakan lembar observasi dengan jumlah item 14,Observasi dilakukan pada hari Selasa, 25 Agustus 2020 pada jam ke-1 (30 menit )yaitu 08.00-08.30 Wita dengan pokok bahasan memahami materi taubat. Adapun kegiatan pembelajaran adalah sebagai berikut: a. Kegiatan awal Siswi sangat mampu untuk menjawab pertanyaan tentang materi sebelumnya, b. Saat mengerjakan tugas kelompok, 
siswi seringkali menanyakan yang kurang jelas kepada guru. Skor keaktifan yang diperoleh dari observasi siklus 2. c. Dalam prensentasi hasil diskusi 2 siswi yang dari kelompok lain sangat aktif menanggapinya.

Tabel 2. Nilai Kriteria Berpikir Kritis Siswi

\begin{tabular}{|c|c|c|c|c|c|c|}
\hline \multirow{2}{*}{ No } & \multirow{2}{*}{ Nama } & \multicolumn{4}{|c|}{ Skor } & \multirow{2}{*}{ Nilai } \\
\hline & & 1 & 2 & 3 & 4 & \\
\hline 1 & Adiska & & & & $\checkmark$ & 100 \\
\hline 2 & Azizah & & & $\checkmark$ & & 95 \\
\hline 3 & Delima & & & $\checkmark$ & & 95 \\
\hline 4 & Fitri Aziah & & & $\checkmark$ & & 89 \\
\hline 5 & Helda Wati & & & $\checkmark$ & & 95 \\
\hline 6 & Khadijah & & & & $\checkmark$ & 100 \\
\hline 7 & Khalidah & & & $\checkmark$ & & 88 \\
\hline 8 & Mahdalina & & & & $\checkmark$ & 100 \\
\hline 9 & Mildawati & & & & $\checkmark$ & 100 \\
\hline 10 & Mutia & & & $\checkmark$ & & 95 \\
\hline 11 & Nurul Aida & & & & $\checkmark$ & 100 \\
\hline 12 & Ratna & & & $\checkmark$ & & 95 \\
\hline 13 & Saidatul Karimah & & & $\checkmark$ & & 95 \\
\hline 14 & Siti Zahra & & & $\checkmark$ & & 87 \\
\hline & Jumlah & & & & & 1334 \\
\hline & Rata-rata & & & & & 95 \\
\hline
\end{tabular}

Untuk skor $1=0-75$, skor $2=76-85$,skor $3=86-95$ skor $4=96-100$

Pedoman penilaian hasil tes berdasarkan rubrik skor berpikir kritis. Adapun perhitungannya dengan rumus-rumus berikut. Untuk menghitung skor rata-rata hasil tes kemampuan berpikir kritis siswa menggunakan rumus Keterangan: Mx = Mean yang kita cari (skor rata-rata) $\Sigma x=$ Jumlah dari skor-skor (nilai-nilai) yang ada $\mathrm{N}=$ Jumlah Ideal (banyaknya skor-skor itu sendiri) Hasil perhitungan nilai rata-rata tes yang telah diperoleh pada setiap siklusnya.

Skor $1=0$ siswi

Skor $2=0$ siswi

Skor $3=9$ siswi

Skor $4=5$ siswi

Dilihat dari banyak skor dari jumlah siswi maka skor 4 berjumlah 5 siswi nilai dari $96-100$

Indikator keberhasilan dalam penelitian ini adalah sebagai berikut: a. Sebanyak $\geq 95 \%$ siswi dapat memahami materi Taubat, b. Ketuntasan belajar tercapai jika 95\% siswi mendapat nilai $\geq$ 95, c. Untuk kriteria keaktifan siswi mendapat nilai baik, dilihat dari hasil penilaian instrument di atas.

Keterampilan proses pembelajaran Aqidah Akhlak dengan menggunakan pendekatan keterampilan proses ini dipilih karena guru dapat melihat secara langsung keaktifan siswa dalam melaksanakan kegiatan pembelajaran sehingga akan meningkatkan pemahaman siswa terhadap materi pelajaran yang disampaikan oleh guru melalui video pembelajaran.

2. Deskripsi Hasil Penelitian Siklus 2

a. Perencanaan Perencanaan pelaksanaan penelitian tindakan kelas pada siklus 2 mengacu pada hasil observasi siklus 1 yang dilaksanakan pada pembelajaran Aqidah Akhlak dengan Standar Kompetensi mengidentifikasi materi taubat serta Kompetensi Dasar menganalisis konsep,dalil dan dampak positif taubat, serta mengkomunikasikan contoh kisah taubat dalam kehidupan. Dari hasil observasi awal, permasalahan yang ditemui adalah sebagai berikut: 1. Siswi mampu menguasai materi yang diajarkan guru. 2. Keaktifan siswi dalam 
mengikuti kegiatan pembelajaran Aqidah Akhlak tinggi. 3. Penggunaan pendekatan pembelajaran mengunakan media (HP, LCD, Internet).

Dari permasalahan yang ada, maka diputuskan untuk tidak lagi melakukan perbaiakan pembelajaran untuk meningkatkan keaktifan mata pelajaran Aqidah Akhlak. Keterampilan proses pada siswi kelas VII B MTs Al-Hidayah Sungai Tabukan Kecamatan Sungai Tabukan Kabupaten Hulu Sungai Utara Tahun Pelajaran 2020/2021. Untuk mengoptimalkan pelaksanaan pembelajaraan, maka di Susun perencanaan sebagai berikut: 1. kembali Menyusun RPP dengan memperhatikan kelebihan dan kelemahan siswi. 2. Menyiapkan media pembelajaran, 3. Menyiapkan lembar observasi. 4. Menentukan pelaksanaan observasi, dan 5. Menyiapkan alat evaluasi.

b. Pelaksanaan, Pelaksanaan perbaikan pembelajaran pada siklus 2 dalam kali pertemuan yaitu hari Selasa tanggal 25 Agustus 2020 dan pertemuan adalah $1 \times 30$ menit atau 1 jam pelajaran, yang terbagi dalam kegiatan awal, kegiatan inti (Stimulus, Mengidentifikasi Masalah, Data collection (pengumpulan data, Data processing (pengolahan Data)), dan kegiatan akhir. 1) Pertemuan Pertama a) Kegiatan Awal Pada kegiatan awal pembelajaran, guru membuka pelajaran dengan mengucapkan salam, berdoa dan mengabsen siswi dilanjutkan guru melakukan(pemanasan) melalui apersepsi dengan cara mengajukan pertanyaan untuk mengetahui pengetahuan awal siswi, sehingga tercipta dialog. Siswi juga menyimak penjelasan guru tentang tujuan dari kegiatan pelajaran materi taubat (mengamati/indra pendengaran). b) Kegiatan Inti (1) siswi juga menyimak video pembelajaran dan setelah itu membentuk kelompok ada 3 bagian dengan menyesuaikan nama yang sudah dibagi dan juga sesuai gambar 1 sampai 3 mengamatinya di layar LCD selesai mengerjakan maka dilaksanakan presentasi hasil diskusi dan kelompok lain menanggapi agar terjadi keaktifan siswi memberikan pertanyaan dan menjawab pertanyaan yang diberikan dari kelompok lain. mendengarkan penjelasan guru dalam menyimpulkan materi taubat. Kegiatan pembelajaran ditutup dengan doa dan salam.

\section{KESIMPULAN}

Penelitian Tindakan Kelas (PTK) pada siswi kelas VII B MTs Al-Hidayah tahun pelajaran 2020/2021 dilaksanakan dalam dua siklus. Setiap siklus terdiri atas empat tahapan, yaitu: (1) perencanaan, (2) pelaksanaan tindakan, (3) observasi, dan (4) refleksi. Berdasarkan pembahasan dan hasil penelitian maka dapat disimpulkan sebagai berikut: Pembelajaran materi taubat dengan menggunakan metode Saintifik/inquiry pada siswi kelas VII B dirasa dapat meningkatkan proses pembelajaran materi taubat. Dimana dapat dilihat dari peningkatan rata-rata perolehan skor dari siklus 1 sebesar $(85 \%)$ dan meningkat pada siklus 2 sebesar (95\%). Implikasi Penelitian ini memberikan suatu gambaran yang jelas bahwa keberhasilan proses pembelajaran tergantung pada beberapa faktor. Faktor-faktor tersebut bisa berasal dari pihak guru, siswa, alat atau media bahkan metode pembelajaran yang digunakan. Kemampuan guru dalam mengembangkan materi, menyampaikan materi, mengelola kelas, metode yang digunakan dalam proses pembelajaran, serta teknik yang digunakan oleh guru sebagai sarana untuk menyampaikan materi supaya siswa lebih antusias dan mampu berpartisipasi aktif dalam kegiatan pembelajaran.

\section{DAFTAR PUSTAKA}

Bogdan, R., \& Biklen, S. 1982. qualitative research in education, Allyn \& Bacon, Boston

Dakir, 1993. Dasar-Dasar Psikologi, Pustaka Pelajar, Yogyakarta

Djalali, M. As'ad. 2001. Psikologi_Motivasi Minat Jabatan, Intelegensi, Bakat dan Motivasi Kerja, Wineka Media, Malang

Djamarah, S. B. 2002. Psikologi Belajar, PT. Rineka Cipta, Jakarta

Guba, E.G., \& Lincoln, Y.S. 1981. Effective Evaluation, Jossey-Bass Publishers, Sanfransisco 
Hamalik, O. 2002. Perencanaan Pengajaran Berdasarkan Pendekatan Sistem, PT. Bumi Aksara, Jakarta Hamalik, Oemar. 2002. Psikologi Belajar dan Mengajar, Penerbit Sinar Baru Algensindo, Bandung Kosasih, Andreas. 2004. Peranan Motivasi terhadap Hasil Belajarnya Siswa, Tabularasa, Vol. 2, No. 3

Miles, M.B., \& Huherman, A.M. 1984. .Analisis Data Kualitatif. Terjemahan oleh Tjejep Rohendi Rohidi, Universitas Indonesia, Jakarta

Moeleng, L.J. 2000. Metodologi Penelitian Kualitatif. PT. Remaja Rosdakarya, Bandung

Nasution, S. 1998. Metode Penelitian .Naturalistic Kualitatif, Penerbit Tarsito, Bandung

Nurhadi, 2002. Pendekatan Kontekstual, Universitas Negeri Malang, Malang

Safaruddin, S., Degeng, I., Setyosari, P., \& Murtadho, N. (2020). The Effect of PjBL with WBL Media and Cognitive Style on Studentsâ€ $€^{\mathrm{TM}}$ Understanding and Science-Integrated Concept Application. Jurnal Pendidikan IPA Indonesia, 9(3), 384-395. Doi: https:/ / doi.org/10.15294/jpii.v9i3.24628

Zuriah, N. 2003. Penelitian Tindakan Bidang Pendidikan Dan Sosial, edisi pertama, 13ayu Media Publishing, Malang 